\title{
Isonatraemic haemodialysis in the management of salt and water overload: a crossover trial at an academic hospital in Dakar, Senegal
}

\author{
Moustapha Faye',2, Bacary Ba', Niakhaleen Keita', Sidy Mohamed Ba', Cheikh Ahmed Tidiane Coulibaly', Ibrahima Thioune', \\ Maria Faye ${ }^{1,2}$, Ahmed Tall Lemrabott',2, Abdou Niang ${ }^{2,3}$, Elhadji Fary Ka',2 \\ 'Nephrology, Dialysis and Renal Transplant Department, Aristide Le Dantec Hospital, Dakar, Senegal; '2Cheikh Anta Diop University, \\ Dakar, Senegal; ${ }^{3}$ Nephrology and Dialysis Department, Dalal Jamm, Dakar, Senegal.
}

\section{ABSTRACT}

Introduction: The aims of this study were to assess the impact of isonatraemic haemodialysis on reduction of interdialytic weight gain (IDWG) and blood pressure (BP) as well as its tolerability in our study population.

Methods: This crossover trial, at the Aristide Le Dantec University Hospital in Senegal, was conducted on 32 patients with kidney failure who were stable on treatment with chronic haemodialysis. In the initial "control phase", patients had nine haemodialysis sessions with a dialysate sodium $\left(\mathrm{Na}^{+}\right)$concentration ( $\mathrm{Na}^{+}$dialysate) of I $38 \mathrm{mmol} / \mathrm{L}$. The serum $\mathrm{Na}^{+}$set point (SP) for each patient was calculated from three predialytic mid-week values. In the second phase, the "individualized phase", patients had nine haemodialysis sessions with $\mathrm{Na}^{+}$dialysate equal to their SP.

Results: The mean age of the patients was $55.5 \pm 12.1$ years, with a male/female ratio of 1.3 and the most common cause of kidney disease was hypertension (47\%). Mean predialytic serum $\mathrm{Na}^{+}$concentration was $135.8 \pm 1.9$ $\mathrm{mmol} / \mathrm{L}$, with a mean intra-individual coefficient of variation of $2 \%$. Mean interdialytic weight gain (IDWG) was I.9 $\mathrm{kg}$ and $1.8 \mathrm{~kg}$ in the control and individualized phases, respectively $(P=0.75)$. A reduction in postdialytic systolic blood pressure (BP) was observed during the individualized phase $(P=0.04)$. A similar trend was noted in pre- and intradialytic BP but this was not statistically significant. Apart from headaches, which were more common in the individualized phase $(P=0.04)$, isonatraemic haemodialysis was well tolerated.

Conclusions: IDWG as well as pre- and intradialytic BP were unaffected by isonatraemic haemodialysis. Postdialytic $\mathrm{BP}$ was significantly reduced.

Introduction: Les objectifs de cette étude étaient d'évaluer l'impact de l'hémodialyse isonatrémique sur la réduction de la prise de poids inter-dialytique (PPID) et de la pression artérielle (PA) ainsi que sa tolérance dans notre population d'étude.

Méthodes: Cet essai croisé a été mené au centre hospitalier universitaire Aristide Le Dantec de Dakar (Sénégal) chez des patients hémodialysés chroniques. Durant la première phase dite « phase contrôle », les patients ont eu neuf séances d'hémodialyse avec une concentration de sodium dans le dialysat ( $\mathrm{Na}^{+}$dialysat) de $138 \mathrm{mmol} / \mathrm{L}$. Le set-point (SP) de la natrémie a été calculé pour chaque patient et correspondait à la moyenne de 3 natrémies prédialytiques en milieu de semaine. Durant la deuxième phase dite « phase individualisée », les patients ont eu neuf séances d'hémodialyse avec du $\mathrm{Na}^{+}$dialysat égal à leur SP.

Résultats: Trente-deux patients ont été inclus. L'âge moyen était de 55,5 \pm I2,I ans avec un ratio homme/femme de I,3 et la néphropathie initiale la plus fréquente était l'hypertensive (47\%). La natrémie pré-dialytique moyenne était de 135,8 \pm 1,9 mmol/L, avec un coefficient de variation intra-individuel moyen de $2 \%$. La PPID moyenne était de $1,9 \mathrm{~kg}$ et $1,8 \mathrm{~kg}$ dans les phases de contrôle et individualisé, respectivement $(P=0,75)$. Une diminution de la PA systolique post-dialytique a été observée au cours de la phase individualisée $(P=0,04)$. Une tendance similaire sans significativité statistique a été notée sur les PA pré- et intra-dialytiques. Hormis les céphalées, plus fréquentes pendant la phase individualisée $(P=0,04)$, l'hémodialyse isonatrémique a été bien tolérée.

Conclusions: La PPID, les PA pré- et intra-dialytiques n'ont pas été affectées par l'hémodialyse isonatrémique. La PA post-dialytique était significativement réduite.

Keywords: isonatraemic haemodialysis; interdialytic weight gain; blood pressure; Senegal. 


\section{INTRODUCTION}

Chronic accumulation of sodium and water contributes to cardiovascular risk in patients with kidney failure who are being treated with maintenance haemodialysis. The volume overload is involved in the pathogenesis of hypertension, left ventricular hypertrophy (LVH) and sudden death [I-3]. Several strategies have been successfully implemented to improve the salt and water status, such as sodium restriction [4,5], increasing the frequency and duration of haemodialysis sessions [6,7], volume management using bioimpedance [8,9] and, more recently, individualized prescription of the dialysis sodium concentration ( $\mathrm{Na}^{+}$dialysate) [10-12].

Isonatraemic haemodialysis has been shown to improve haemodynamic tolerance of the dialysis procedure in patients over 70 years [13]. There are several variations, including isonatraemic, isoconductive and isotonic haemodialysis. Isonatraemic haemodialysis matches the $\mathrm{Na}^{+}$ dialysate to the patient's average pre-dialysis serum $\mathrm{Na}^{+}$ concentrations, the "set point" (SP) [ I 4]. In one study of 27 patients, isonatraemic haemodialysis reduced interdialytic weight gain (IDWG). There were also improvements in thirst score, blood pressure (BP) control and decreased intradialytic hypotension [ I0].

To our knowledge, no previous work on isonatraemic haemodialysis or individualized $\mathrm{Na}^{+}$dialysate prescription has been conducted in Senegal. This trial was performed to assess the impact of isonatraemic haemodialysis on the reduction of IDWG and BP. We also aimed to assess its tolerability, focusing on intradialytic hypotension and cramping during haemodialysis sessions.

\section{METHODS}

A crossover trial was conducted at the Aristide Le Dantec University Hospital in Dakar, Senegal, from I April to 15 May 2020, in patients with kidney failure who were stable on treatment with chronic haemodialysis.

The study was performed in two phases: first, a "control phase", during which patients had three weeks of haemodialysis (nine sessions of treatment) with a standard $\mathrm{Na}^{+}$dialysate of $138 \mathrm{mmol} / \mathrm{L}$. During this phase, the serum $\mathrm{Na}^{+}$set point (SP) for each patient was calculated from three predialytic mid-week values, and the intra-individual variability and the coefficient of variation of natraemia were calculated [10]. All events occurring during haemodialysis sessions and those reported by the patient during the interdialytic periods were recorded. $\mathrm{Na}^{+}$measurements used an ion-selective electrode (ARCHITECT ci4IO analyser, Abbott Laboratories).
In the second phase, the "individualized phase", patients who had completed the control phase had three weeks of haemodialysis with a $\mathrm{Na}^{+}$dialysate equal to their SP. Haemodialysis parameters and intra- and interdialytic events were again recorded. Intra-individual variability in serum $\mathrm{Na}^{+}$concentrations were calculated by the difference between the minimum and the maximum concentrations for each patient. The coefficient of variation was equal to the ratio of the standard deviation to the mean of the serum $\mathrm{Na}^{+}$concentration for each patient.

Patients were included if they were over 18 years of age, stable on chronic haemodialysis for more than three months, receiving three treatment sessions per week and had signed written informed consent. Diabetic patients, anyone who had a serious cardiovascular event in the preceding three months, and those using a temporary haemodialysis catheter or who had vascular access dysfunction were not included.

Data were captured using Microsoft Excel and analysed using $R$ software version 4.03. Numerical variables were summarised using mean and standard deviation and categorical variables were summarised using counts and proportions. The control and individualized phases were compared using paired $z$ tests and McNemar's tests. A P value of $<0.05$ was considered statistically significant.

The study was approved by the Ethics Committee of the Department of Medicine of Cheikh Anta Diop University of Dakar (study registration number 033/2020/CER/ UCAD). All patients provided written, informed consent. The work was not supported by any external funding.

\section{RESULTS}

Of 100 patients on chronic haemodialysis at our centre, 60 were included in the study. Only 32 had complete measurements and could be included in the analysis (Figure I). Their mean age was $55.5 \pm 12.1$ years, with a male/ female ratio of 1.3. Anaemia was noted in 22 patients (69\%); I 3 patients (41\%) had haemoglobin concentrations between $9 \mathrm{~g} / \mathrm{dL}$ and $\mid \mathrm{I} \mathrm{g} / \mathrm{dL}$ and iron deficiency was noted in 7 patients (22\%). Secondary hyperparathyroidism was present in 21 patients and vitamin D deficiency in 11 patients. Cardiac ultrasound performed on 20 patients (63\%) reported left ventricular hypertrophy in 18. The mean left ventricular ejection fraction was $65.3 \pm 9.6 \%$. Twenty-one patients (66\%) were receiving antihypertensive treatment (Table I).

The mean serum $\mathrm{Na}^{+}$concentration was $135.8 \pm 1.9$ $\mathrm{mmol} / \mathrm{L}$, with a mean coefficient of variation of $2 \%$ and mean intra-individual variability of $4.6 \pm 2.9 \mathrm{mmol} / \mathrm{L}$. Sixty percent of predialytic measurements were between 


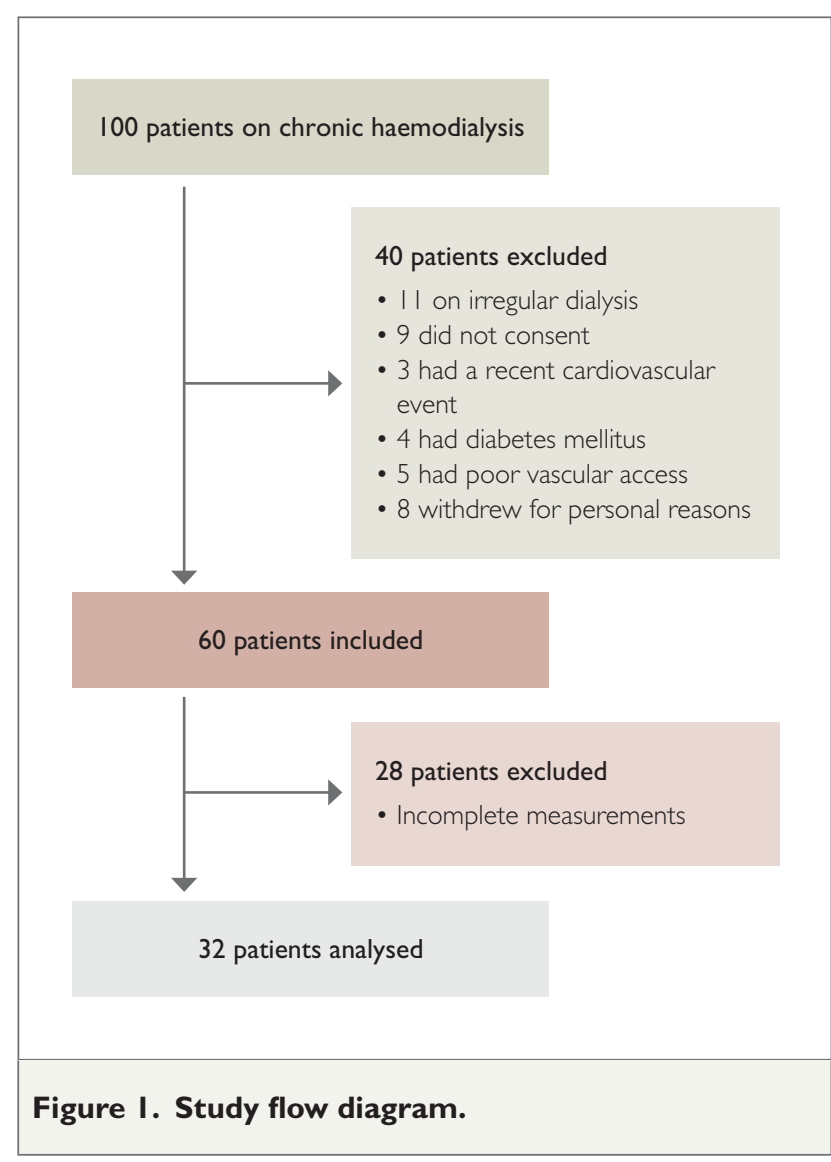

$135 \mathrm{mmol} / \mathrm{L}$ and $139 \mathrm{mmol} / \mathrm{L}$ (Figure 2). Set points between $135 \mathrm{mmol} / \mathrm{L}$ and $136 \mathrm{mmol} / \mathrm{L}$ were the most common ( 13 patients, $41 \%)$. See Figure 3.

The mean serum potassium concentration was $4.3 \pm$ $0.9 \mathrm{mmol} / \mathrm{L}$. Sixty-nine percent of patients had a serum potassium concentration between $4.0 \mathrm{mmol} / \mathrm{L}$ and 5.0 $\mathrm{mmol} / \mathrm{L}$. Hyperkalaemia was noted in $11 \%$.

The mean ultrafiltration (UF) volume was slightly higher in the control phase, but this was not statistically significant ( $1.9 \mathrm{~L}$ vs $1.8 \mathrm{~L} ; \mathrm{P}=0.70$ ). The mean IDWG was $1.9 \mathrm{~kg}$ vs $1.8 \mathrm{~kg}$ in the control and individualized phases, respectively $(P=0.75)$. A significant reduction in postdialytic systolic $\mathrm{BP}$ was observed during the individualized phase (I48 $\mathrm{mmHg}$ vs $135 \mathrm{mmHg} ; P=0.04)$. This trend was also observed with the pre- and intradialytic BP without reaching statistical significance (Table 2 ).

Qualitative parameters documented during the two phases are summarised in Table 3. Headaches were more frequent during the individualized phase ( 8 vs 5 episodes; $P=0.04$ ). There was no difference between the two phases on intraand postdialytic symptoms (cramps, hypotension and intradialytic hypertension).

\section{DISCUSSION}
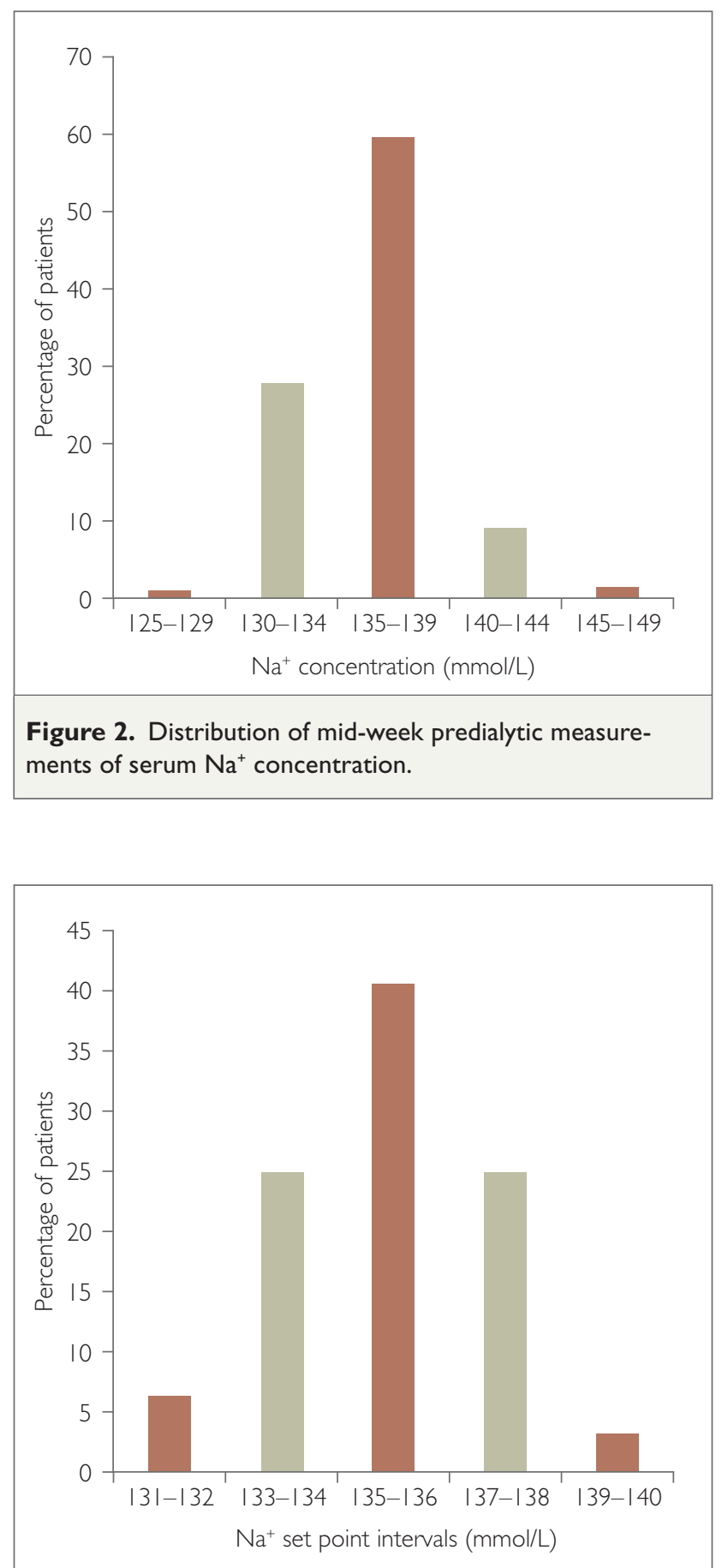

Figure 3. Distribution of patients according to serum $\mathrm{Na}^{+}$set points.

intradialytic BP. Post-dialysis systolic BP was significantly reduced. Our results are similar to those of Thein et al. [15] but differ from other studies. Aramreddy [16] reported a significant reduction of IDWG after a decrease in $\mathrm{Na}^{+}$ dialysate by $2 \mathrm{mmol} / \mathrm{L}$, and Elshahawy et al. [17] found that the individualization of $\mathrm{Na}^{+}$dialysate was associated with a decrease of IDWG and better BP control. This effect was also reported in the DISO trial [ 8$]$.

Several studies have reported reductions of predialytic systolic BP and non-significant reductions in postdialytic 
Table I. Baseline characteristics of patients $(n=32)$.

\begin{tabular}{|c|c|c|}
\hline & & Mean \pm standard deviation \\
\hline \multicolumn{2}{|l|}{ Age (years) } & $55.5 \pm 12.1$ \\
\hline \multicolumn{2}{|l|}{ Dialysis duration (months) } & $104 \pm 43$ \\
\hline \multicolumn{2}{|l|}{ Dry weight (kg) } & $63.6 \pm 17.0$ \\
\hline \multicolumn{2}{|l|}{ IDWG (kg) } & $1.6 \pm 0.6$ \\
\hline \multicolumn{2}{|l|}{ Haemoglobin (g/dL) } & $10.1 \pm 2.5$ \\
\hline \multirow{2}{*}{\multicolumn{2}{|c|}{ Haematocrit (\%) }} & $31.9 \pm 7.2$ \\
\hline & & Count (\%) \\
\hline \multirow[t]{2}{*}{ Sex } & $\mathrm{F}$ & I5 (46.9) \\
\hline & M & $17(53.1)$ \\
\hline \multirow[t]{5}{*}{ Primary kidney disease } & Hypertension & I5 (46.9) \\
\hline & Unknown & $8(25.0)$ \\
\hline & Chronic glomerulonephritis & $7(21.9)$ \\
\hline & Postpartum kidney failure & I (3.1) \\
\hline & Adult polycystic kidney disease & I (3.1) \\
\hline \multirow[t]{2}{*}{ Comorbid conditions } & Pulmonary tuberculosis & $2(6.3)$ \\
\hline & Other & $3(9.4)$ \\
\hline \multirow[t]{3}{*}{ Vascular access } & Distal arteriovenous fistula & $18(56.3)$ \\
\hline & Proximal arteriovenous fistula & $10(3 \mid .2)$ \\
\hline & Tunnelled catheter & $4(12.5)$ \\
\hline \multirow[t]{2}{*}{ Clinical } & Residual urine output & $9(28.1)$ \\
\hline & Intradialytic hypotension & $4(12.5)$ \\
\hline \multirow[t]{11}{*}{ Medications } & ARBs & $10(3 \mid .2)$ \\
\hline & ACEi & $8(25.0)$ \\
\hline & Calcium channel blockers & $3(9.4)$ \\
\hline & Beta blockers & $4(12.5)$ \\
\hline & Rilmenidine & $3(9.4)$ \\
\hline & Calcium supplementation & $5(15.6)$ \\
\hline & Vitamin D supplementation & $5(15.6)$ \\
\hline & Erythropoietin & $3(9.3)$ \\
\hline & PPIs & $2(6.3)$ \\
\hline & Intravenous iron therapy & $2(6.3)$ \\
\hline & NSAIDs & I (3.1) \\
\hline
\end{tabular}

Abbreviations: ACEi, angiotensin conversion enzyme inhibitors; ARBs, angiotensin receptor blockers; PPIs, proton pump inhibitors; NSAIDs, non-steroidal anti-inflammatory drugs; IDWG = interdialytic weight gain; Other, sickle cell anaemia, autoimmune haemolytic anaemia and peptic ulcer disease.

systolic BP $[10,17]$. The reduction in BP has been reported by other studies where $\mathrm{Na}^{+}$dialysate was reduced without being isonatraemic $[1 \mid, 15]$. The improvement in BP is linked to the reduction of IDWG. However, we did not the beneficial effect on BP of isonatraemic haemodialysis may not be related solely to blood volume control.

In our study, the mean predialytic serum $\mathrm{Na}^{+}$concentration was $135.8 \mathrm{mmol} / \mathrm{L}$. This is similar to that reported by De 
Table 2. Effect of isonatraemic haemodialysis on quantitative parameters.

\begin{tabular}{|c|c|c|c|}
\hline & Control phase & Individualized phase & $P$ value \\
\hline \multicolumn{4}{|l|}{ Predialytic parameters } \\
\hline Weight (kg) & $64.3 \pm 16.9$ & $65.2 \pm 17$ & 0.52 \\
\hline IDWG (kg) [\%] & $1.9 \pm 1.0[3.1]$ & $1.8 \pm 1.1[2.9]$ & 0.75 \\
\hline Systolic BP (mmHg) & $144 \pm 25$ & $136 \pm 29$ & 0.28 \\
\hline Diastolic BP (mmHg) & $88 \pm 17$ & $78 \pm 16$ & 0.51 \\
\hline \multicolumn{4}{|l|}{ Intradialytic parameters } \\
\hline Systolic BP (mmHg) & $|4| \pm 56.0$ & $140 \pm 30$ & 0.99 \\
\hline Diastolic BP (mmHg) & $79 \pm 16$ & $77 \pm 16$ & 0.98 \\
\hline \multicolumn{4}{|l|}{ Postdialytic parameters } \\
\hline Weight (kg) & $63.0 \pm 16.8$ & $62.5 \pm 16.9$ & 0.90 \\
\hline Ultrafiltration volume (L) & $1.9 \pm 0.7$ & $1.8 \pm 0.7$ & 0.70 \\
\hline Systolic BP (mmHg) & $|48 \pm 3|$ & $135 \pm 32$ & 0.04 \\
\hline Diastolic BP (mmHg) & $84 \pm 16$ & $79 \pm 18$ & 0.14 \\
\hline
\end{tabular}

Abbreviations: IDWG, interdialytic weight gain.

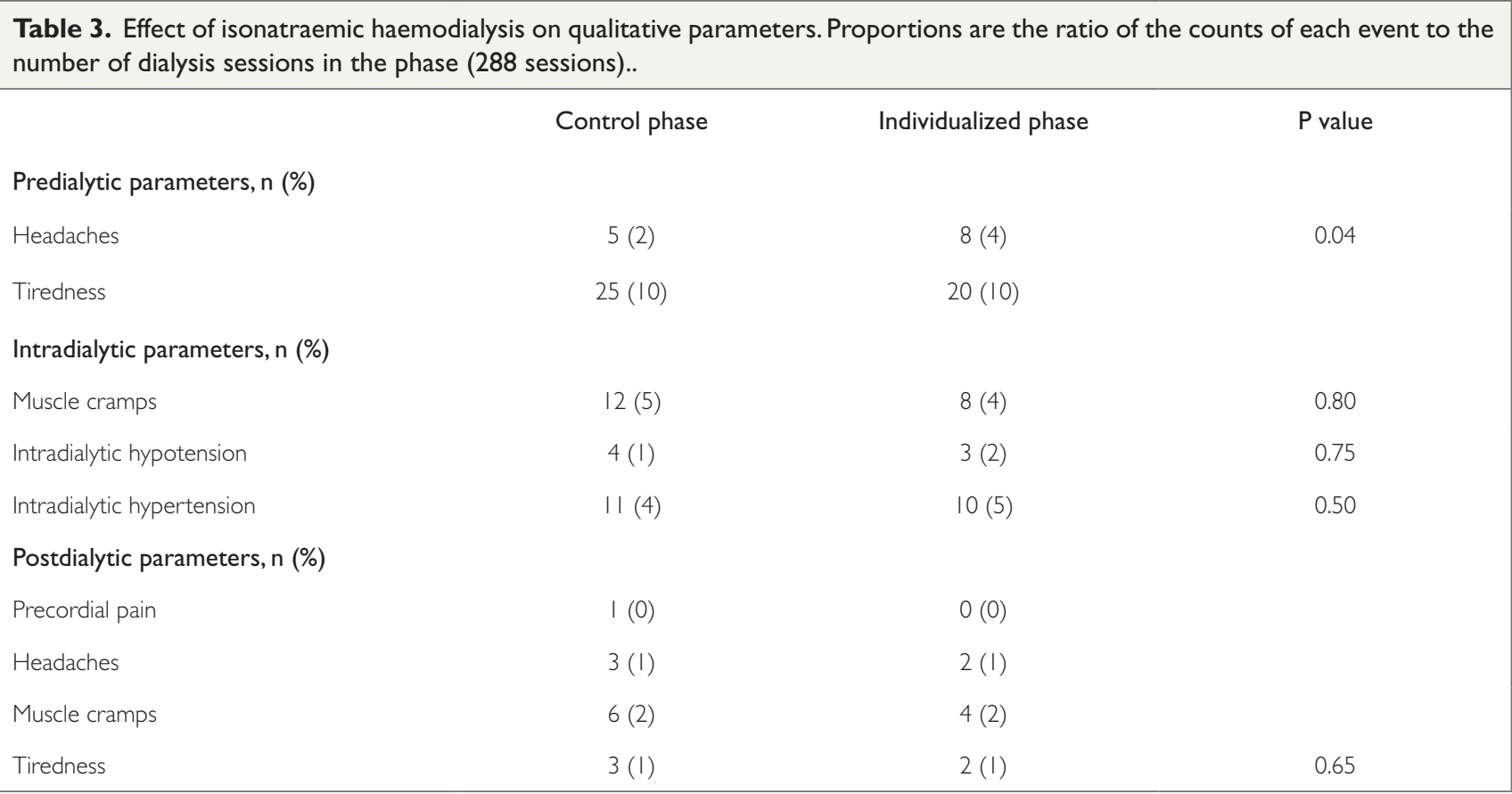

Paula et al. (I $34.0 \mathrm{mmol} / \mathrm{L})$ [I0] and Aramreddy et al. ( $135.5 \mathrm{mmol} / \mathrm{L}$ ) [16]. In the study by Radhika et al. [18], mean predialytic $\mathrm{Na}^{+}$concentration was higher (I38.7 $\mathrm{mmol} / \mathrm{L})$. Forty-one percent of our patients had an SP of | 35-136 mmol/L and $72 \%$ had an SP <136 mmol/L. The mean SP was lower than the $\mathrm{Na}^{+}$concentration of the standard dialysate used in our haemodialysis units (I 35.8 vs $138 \mathrm{mmol} / \mathrm{L})$. This dialysate solution is therefore hypernatraemic for most patients and would predispose to salt and water overload.
Apart from the headaches that were more frequent in the individualized phase, isonatraemic haemodialysis was well tolerated. This finding is corroborated by several other studies $[16,18]$. In an older study, De Paula et al. noted better tolerance with a significant reduction in intradialytic hypotension [10]. This effect of isonatraemic haemodialysis might be related to better volume control with a reduction in UF volumes. 
Equipping our haemodialysis units with machines able to perform online measurement of $\mathrm{Na}^{+}$concentration or conductivity would seem to be the best way to demonstrate the clinical benefits of isonatraemic haemodialysis in its isoconductive form. Isonatraemic haemodialysis must be integrated into the therapeutic arsenal, which would also include patient education on salt and water intake.

The relatively small sample population and the short duration were limitations of our study. The benefits of isonatraemic haemodialysis can be delayed, occurring months after starting the intervention.

\section{CONCLUSIONS}

IDWG as well as pre- and intradialytic BP were unaffected by isonatraemic haemodialysis, whereas postdialytic BP was significantly reduced. This is a well-tolerated modality. Upgrading haemodialysis machines to measure conductivity in real time would provide the optimal conditions for performing isonatric haemodialysis.

\section{Acknowledgements}

This work was funded by the Department of Nephrology at Aristide Le Dantec University Hospital. We thank Fatou Diallo and the staff of the biochemistry laboratory at the hospital, and Mouhamadou Moustapha Cisse and the nursing staff of the haemodialysis units.

\section{REFERENCES}

I. Paoletti E, Specchia C, Di Maio G, Bellino D, Damasio B, Cassottana $P$, et al. The worsening of left ventricular hypertrophy is the strongest predictor of sudden cardiac death in haemodialysis patients: A 10-year survey. Nephrol Dial Transplant. 2004; 19: 1829- 834.

2. London GM, Pannier B, Guerin AP, Blacher J, Marchais SJ, Darne B, et al. Alterations of left ventricular hypertrophy in and survival of patients receiving hemodialysis: Follow-up of an interventional study. J Am Soc Nephrol. 200 I; 12:2759-2767.

3. Thomson B, Li L, Lindsay R. Effect of personalized dialysate sodium prescription on plasma sodium concentration and sodium set point in conventional, quotidian and nocturnal home hemodialysis. J Nephrol Ther. 2017; 7:294.

4. Kayikcioglu M, Tumuklu M, Ozkahya M, Ozdogan O, Asci G, Duman $\mathrm{S}$, et al. The benefit of salt restriction in the treatment of end-stage renal disease by hemodialysis. Nephrol Dial Transplant. 2009; 24:956-962.

5. Ozkahya M, Ok E, Cirit M, Aydin S, Akçiçek F, Basçi A, et al. Regression of left ventricular hypertrophy in hemodialysis patients by ultrafiltration and reduced salt intake without antihypertensive drugs. Nephrol Dial Transplant. 1998; |3:|489-| 493.

6. Chan CT, Greene T, Chertow GM, Kliger AS, Stokes JB, Beck GJ, et al. Determinants of left ventricular mass in patients on hemodialysis: Frequent Hemodialysis Network (FHN) trials. Circ Cardiovasc Imaging. 2012; 5:25I-26I.

7. Rocco MV, Lockridge RS, Beck G], Eggers PW, Gassman JJ, Greene T, et al. The effects of frequent nocturnal home hemodialysis: The frequent hemodialysis network nocturnal trial. Kidney Int. 20 I I; 80:|080-1091.
8. Hur E, Usta M, Toz H, Asci G, Wabel P, Kahvecioglu S, et al. Effect of fluid management guided by bioimpedance spectroscopy on cardiovascular parameters in hemodialysis patients: A randomized controlled trial. Am J Kidney Dis. 2013; 61:957-965?

9. Moiss U, Arias-Guillen M, Wabel P, Fontseré N, Carrera M, Campistol JM, et al. Bioimpedance-guided fluid management in hemodialysis patients. Clin J Am Soc Nephrol. 2013; 8: I575-I 582.

10. De Paula FM, Peixoto AJ, Pinto LV, Dorigo D, Patricio PJM, Santos SFF, et al. Clinical consequences of an individualized dialysate sodium prescription in hemodialysis patients. Kidney Int. 2004; 66: I232-1238.

I I. Sayarlioglu H, Erkoc R, Tuncer M, Soyoral Y, Esen R, Gumrukcuoglu $H A$, et al. Effects of low sodium dialysate in chronic hemodialysis patients: An echocardiographic study. Ren Fail. 2007; 29:| 43- 46.

12. Suckling RJ, Swift PA, He FJ, and Markandu ND, MacGregor GA. Altering plasma sodium concentration rapidly changes blood pressure during haemodialysis. Nephrol Dial Transplant. 2013; 28:2181-2186.

13. Goumri N, Lefebvre MM, Thomas K, Sacquepee M, Amirou M. Bénéfice de la dialyse isonatrique chez les patients de plus de 70 ans. Nephrol Ther. 2016; 12:328.

14. Petitclerc T, Gaillard F. Hémodialyse isonatrique: principe et modalités. Nephrol Ther. 2019; 15:22-28

15. Thein H, Haloob I, Marshall MR. Associations of a facility level decrease in dialysate sodium concentration with blood pressure and interdialytic weight gain. Nephrol Dial Transplant. 2007; 22:2630-2639.

16. Arramreddy R, Sun SJ, Munoz Mendoza J, Chertow GM, Schiller B. Individualized reduction in dialysate sodium in conventional in-center hemodialysis. Hemodial Int. 2012; 16:473-480.

17. Elshahawy Y, Sany D, Shawky S. Outcome of individualized dialysate sodium concentration for hemodialysis patients. Saudi J Kidney Dis Transplant. 20 I3; 24:507-5 I 3.

18. Radhika C. R, Santosh V, Abitha C, Jacob S, David VG, Alexander S, et al. Effects of individualized dialysate sodium prescription in hemodialysis - Results from a prospective interventional trial. Indian J Nephrol. 2020; 30:3-7. 